\title{
Exchange Rates and the Prices of Nonfood, Nonfuel Products
}

IT IS OFTEN SAID that the rise in the value of the U.S. dollar since 1980 has played an important role in slowing the inflation rate, and there is a corresponding concern that a sharp drop in the currently high U.S. dollar exchange rate will have a serious inflationary effect. A casual look at recent experience with exchange rate and price movements lends credence to this concern. Table 1 shows that for every year since 1975, a depreciation of the dollar has always been accompanied by a higher inflation rate; and an exchange rate appreciation invariably has been linked with a lower inflation rate. ${ }^{1}$ This paper evaluates whether changes in the exchange rate actually have important effects on the price level. ${ }^{2}$

Exchange rate movements are thought to affect the domestic price level mainly through the prices of imports: exchange rate appreciation makes imports cheaper; this in turn retards increases in the prices of domestic goods through cheaper imported inputs and through competition from cheaper finished imported goods. The import deflator, shown in figure 1, has fallen steadily for the last three years, a period when U.S. inflation was slowing. The import deflator for that period is flat when

This research was supported in part by the National Science Foundation under grant PRA-8211924. I am grateful to Barry P. Bosworth, Ralph C. Bryant, Lawrence B. Krause, Robert Z. Lawrence, and members of the Brookings Panel for helpful conversations. I thank Carl Blackwell and Leslie Lipschitz for data, Linda Mix for able research assistance, and Charlotte Kaiser and Evelyn M. E. Taylor for excellent typing.

1. Except for the 1977 change in the import-share exchange rate index. As shown in table 1 , the extent, and in some years even the direction, of the exchange rate movement depends on the index used, an issue which will be addressed later in the paper.

2. Previous studies on this relationship are surveyed in Peter Hooper and Barbara Lowrey, "Impact of the Dollar Depreciation on the U.S. Price Level: An Analytical Survey of Empirical Estimates," International Finance Discussion Paper 128 (Board of Governors of the Federal Reserve System, January 1979). 
Table 1. Prices and Exchange Rates, 1971-83 ${ }^{\mathrm{a}}$

Annual changes in percent

\begin{tabular}{ccccc}
\hline Year & $\begin{array}{c}\text { Federal } \\
\text { Reserve } \\
\text { exchange } \\
\text { Consumer } \\
\text { price index }\end{array}$ & $\begin{array}{c}\text { Morgan } \\
\text { Guaranty } \\
\text { rachange }\end{array}$ & $\begin{array}{c}\text { import-share } \\
\text { rate index }\end{array}$ & $\begin{array}{c}\text { exchange } \\
\text { rate index }\end{array}$ \\
\hline 1971 & 4.3 & -2.7 & -2.8 & -3.0 \\
1972 & 3.3 & -7.4 & -6.7 & -6.2 \\
1973 & 6.2 & -9.2 & -6.9 & -5.5 \\
1974 & 11.0 & 2.3 & 1.7 & 1.6 \\
1975 & 9.1 & -2.9 & 0.1 & 0.7 \\
1976 & 5.8 & 7.2 & 3.6 & 2.4 \\
1977 & 6.5 & -2.2 & -0.1 & 0.1 \\
1978 & 7.7 & -10.6 & -8.2 & -6.7 \\
1979 & 11.3 & -4.7 & -1.5 & -0.4 \\
1980 & 13.5 & -0.8 & -0.1 & 0.0 \\
1981 & 10.4 & 17.7 & 9.8 & 8.0 \\
1982 & 6.1 & 13.3 & 10.3 & 9.0 \\
1983 & 3.2 & 7.5 & 4.0 & 2.5 \\
\hline
\end{tabular}

Source: Consumer price index, U.S. Bureau of Labor Statistics. The Federal Reserve and Morgan Guaranty exchange rate indexes, various issues of Federal Reserve Bulletin and World Financial Markets, respectively. Importshare exchange rate index, author's calculation.

a. The rates of change are calculated from the average value of the variable in the year. The exchange rate indexes are constructed so that a positive sign indicates appreciation of the dollar with respect to a basket of currencies.

b. Constructed from the bilateral exchange rates of the United States with ten major industrial countries and using as weights their respective shares of global trade during 1972-76. Trade is defined as imports plus exports.

c. Constructed from fifteen currencies whose weights are the 1980 bilateral shares of these countries in U.S. trade in manufacturing.

d. Constructed with the same group of countries used in the Federal Reserve index but using as weights these countries' bilateral shares of total imports of the United States during 1972-76.

one excludes services, petroleum, and food-three categories of imports whose prices vary widely for reasons that are unrelated to national costs. The confluence in the movements of the exchange rate, import prices, and the domestic price level certainly gives the impression that the external sector in the past few years has been an important factor in explaining U.S. inflation.

If the preceding interpretation is correct, then we may now be confronting an important new source of external disturbance besides prices of oil and primary commodities. In the future, will changes in foreign demand, operating via exchange rate movements, rival domestic demand and wage developments as causes of U.S. inflation? Will speculative capital flows be the external shock of the 1980s? To anticipate the empirical results, I argue that the preceding interpretation of the current inflation slowdown exaggerates the international influence. For 
Figure 1. Implicit Import Deflators, 1971 -1984

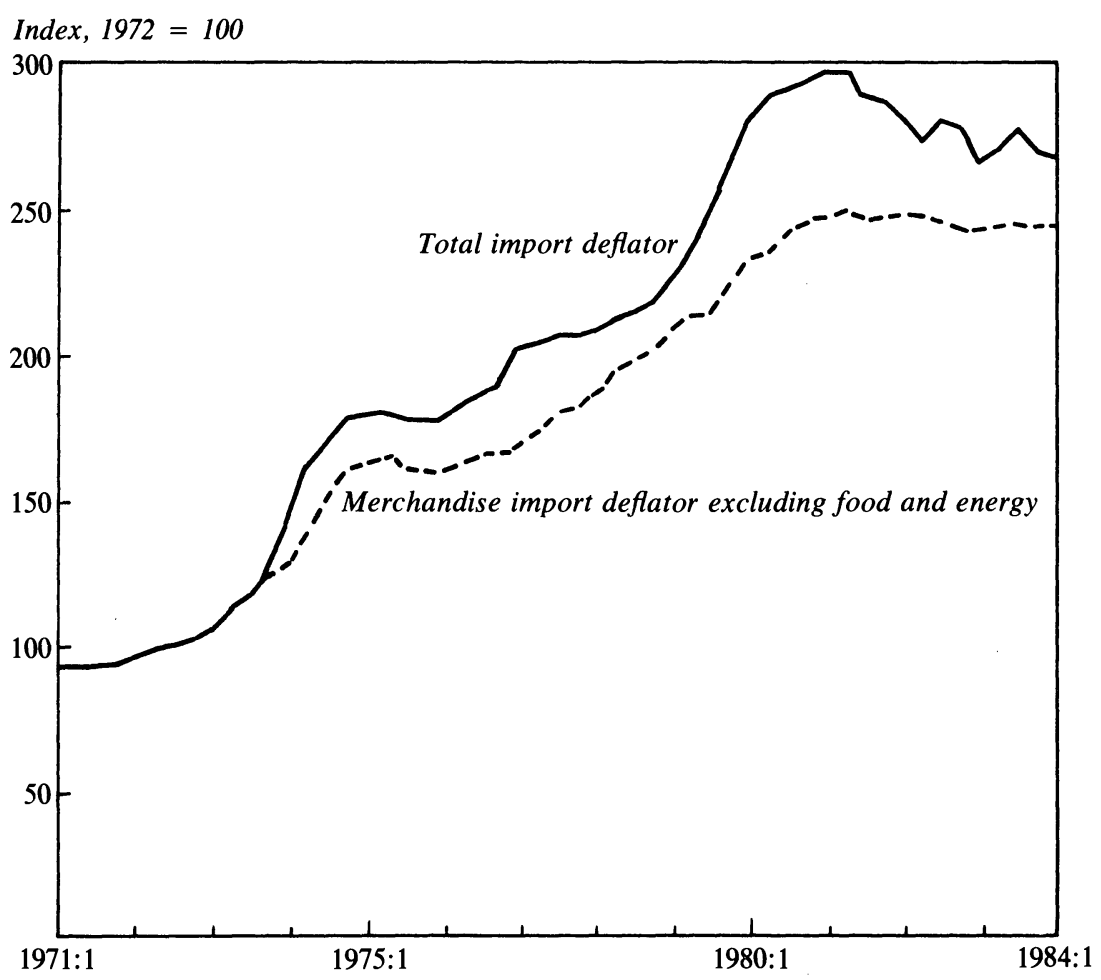

Source: National income and product accounts.

the United States, exchange rate movements have a significant though far from proportional effect on nonfood, nonfuel merchandise import prices; but, surprisingly, these prices in turn have little or no effect on the consumption deflator that excludes food and energy.

Except for the simple doctrine of purchasing-power parity, which has been unable to explain most of the variation in exchange rates that has occurred since 1973, theory predicts no overall correlation between exchange rate movements and price level movements. The fact that such a correlation was not observed before 1975 underscores the point that the analysis of this relationship is not straightforward. A foreign monetary expansion that increases the demand for U.S. exports will tend to raise the U.S. price level while appreciating the dollar. On the other 
hand, a U.S. monetary expansion will raise the U.S. price level while depreciating the dollar. Not only does the sign of the correlation depend on the nature of the disturbance; it also depends on the structure of the economy. Whether an expansionary fiscal policy appreciates or depreciates the exchange rate depends on the response of capital flows to interest rate changes. The greater the response, the more likely the exchange rate will appreciate, as demonstrated in the recent U.S. and French fiscal expansions: the U.S. expansion was accompanied by an appreciation of the U.S. exchange rate, while a depreciation of the French exchange rate accompanied the French expansion.

The key point is that there is no unambiguous relationship between the exchange rate and the price level. To put the statement more formally, a reduced-form relationship does not exist for these two endogenous variables. It does not follow, however, that the widespread concern about the inflationary effect of an exchange rate depreciation is unfounded. The next section makes this issue a well-defined question and shows that the answer to it has important implications for the level of employment and prices. The paper then turns to empirical evidence on the effects of exchange rates and discusses the implications of the empirical results for economic performance.

\section{Defining the Question}

There are at least four channels through which the exchange rate can affect the price level. The first is the prices of imported consumer goods, which directly affect the consumer price index. The second is the prices of imported inputs, which directly affect costs of production. An important question concerning these first two channels is whether the foreign prices of the imports are given and hence whether an exchange rate movement passes entirely onto the U.S. price of the imports. The third is aggregate demand via the trade multiplier; exchange rate movements change the current account position, which in turn affects aggregate demand.

The fourth is foreign prices, which affect the prices of domestically produced competing goods. The effect through this channel is difficult to model because it involves price-setting behavior in sectors of the economy characterized by imperfect competition. If this channel is effective, the price of U.S. exports ought to depend on the price of 
competing goods in foreign markets, and the price of U.S. goods that compete with imports should be affected by the dollar price of these imports. These actions in the domestic tradable goods sector hence tend to raise the U.S. price level when the exchange rate depreciates and to lower it when the exchange rate appreciates.

The importance of these foreign price effects depends, among other things, on the size of U.S. supply and demand in the world market. If the U.S. market is small, foreign prices are fixed in foreign currencies. At the opposite extreme, if the U.S. market is very large, then the dollar prices of tradable goods may be largely independent of exchange rate movements, because both U.S. and foreign firms will price to the U.S. market. But relative market size is only one of the factors that cloud the relationship between the exchange rate and prices of tradable goods. Strategic considerations and institutional factors are also important in oligopolistic situations. Those who export goods to the United States may be sufficiently influenced by U.S. objections to steel and automobile imports that they would not expand their market shares rapidly when the dollar appreciates sharply but instead would choose higher profit margins by maintaining their prices in dollars. Also, firms are less likely to change domestic prices when a change in the exchange rate is perceived to be temporary. Given all these possibilities, the impact of exchange rate movements on the U.S. price level must be determined empirically.

Although a reduced-form relationship between the exchange rate and the price level cannot be derived, a structural relationship between them can be specified based on the channels of influence described above. This structural relationship presumes that pricing behavior for a sizable portion of the economy can be characterized by some version of markup over unit costs. ${ }^{3}$ Such a cost-markup model is inappropriate when applied either to sectors with perfect competition or to sectors that are effectively cartelized. A good example of the former is the market for homogeneous agricultural products, for which climatic conditions can be more important than labor costs in determining prices. If the U.S. market is only a small part of the global market, it may be appropriate to think of these

3. Motivation of such a relationship is given in William Nordhaus, "Recent Developments in Price Dynamics, " in Otto Eckstein, ed., The Econometrics of Price Determination (Washington, D.C.: Federal Reserve Board, 1970), pp. 16-49, and Robert J. Gordon, "The Impact of Aggregate Demand on Prices," $B P E A, 3: 1975$, pp. 613-62. The exact specification depends on assumptions regarding the nature of the demand curve and the type of technological improvement. 
products as having a world price fixed in terms of a basket of currencies and of each country as being a price taker. Then the degree to which exchange rate changes are passed through should be larger for agricultural products than for manufactured goods.

A structural relationship between prices and the exchange rate is also unlikely to hold when a cartel sets the price of the commodity. The costs of organizing and maintaining discipline within a cartel may be lower if the price is set in a particular currency. A good case can be made that, so far, OPEC has been setting the price of oil in U.S. dollars and has been unresponsive to subsequent changes in the exchange rate. At a minimum, OPEC's pricing policy cannot be characterized as a continuous reaction to the dollar exchange rate; therefore, I assume that the price of imported oil is given exogenously. ${ }^{4}$ Furthermore, given the substitution possible between different sources of energy, the price of energy in general is not taken to reflect unit labor cost to an important degree.

Because of these considerations, I apply the cost-markup model to prices of imported and exported goods excluding prices of agricultural products and energy and explain the deflator for consumption excluding food and energy. ${ }^{5}$ I use the price of imported petroleum as an explanatory variable for the consumption deflator in order to take into account the impact of oil prices as an input to other finished goods prices.

To examine the effect of the exchange rate on import and export prices separately from the effect of these prices on the U.S. price level, I estimate empirically three types of equations:

$$
\begin{aligned}
p_{m} & =\alpha_{0}+\alpha_{1} c+\alpha_{2} e+\alpha_{3} c_{f}, \\
p_{x} & =\beta_{0}+\beta_{1} c+\beta_{2} e+\beta_{3} c_{f}, \\
p & =\gamma_{0}+\gamma_{1} w+\gamma_{2} p_{m}+\gamma_{3} p_{x}+\gamma_{4} p_{\text {oil }},
\end{aligned}
$$

4. A survey of our ignorance concerning OPEC's pricing policy is Dermot Gately, "A Ten-Year Retrospective: OPEC and the World Oil Market," Journal of Economic Literature, vol. 23 (September 1984), pp. 1100-14. Gately may share my opinion that exchange rate movements have no predictable impact on OPEC pricing behavior, because the exchange rate is not mentioned anywhere in his survey. It is interesting that both the 1973-74 quadrupling and the 1979-80 doubling of the price of oil were preceded by substantial dollar depreciations.

5. The analysis is restricted to merchandise trade because the bulk of services is remittance of dividends and interest payments. 
where all variables are expressed as natural logarithms and are defined as follows:

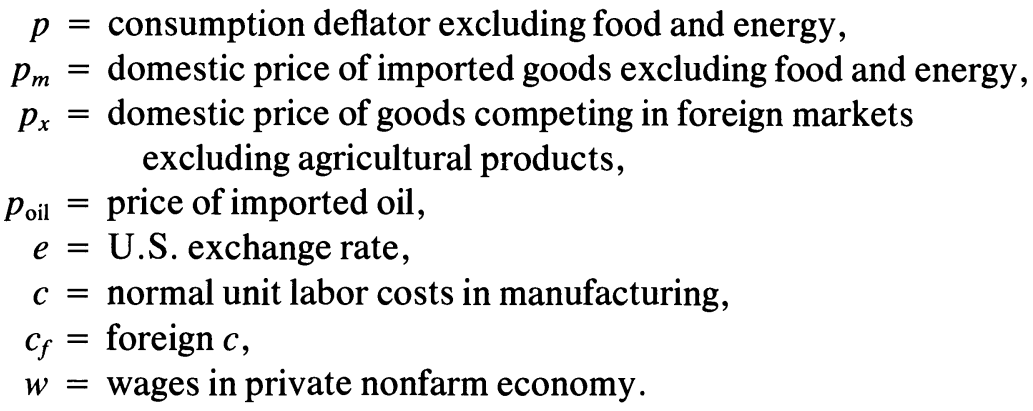

In addition, I estimate directly the effects on $p$ of the determinants of $p_{m}$ and $p_{x}$ through an equation of the form

$$
p=\delta_{0}+\delta_{1} w+\delta_{3} c_{f}+\delta_{3} e+\delta_{4} p_{\text {oil }} .
$$

Four proxies for the demand variable (capacity utilization rate in the manufacturing sector, the Perry-weighted unemployment rate, the ratio of unfilled orders in manufacturing industries to gross national product, and the ratio of new orders in manufacturing to GNP) were tried in all the above equations, but they never entered significantly and were dropped.

Equations 3 and 4 focus on the price effects of an exchange rate movement when policies stabilize aggregate demand. The effect of demand, which does not enter directly in the equations, appears in other variables such as labor costs. To be specific, equations 3 and 4 allow one to answer the following question, which underlies today's concern about the fall of the dollar exchange rate: if a shift in portfolio preferences away from dollar-denominated assets depreciates the dollar, and fiscal and monetary policies offset all changes in aggregate demand, what is the impact on the price level? The more general question of the price effects of a shift away from dollar-denominated assets when policy instrument settings are kept fixed cannot be answered without reference to a full econometric model. The partial equilibrium approach focuses exclusively on the price effects of exchange rate movements without having to consider the cause of the change in the exchange rate. 


\section{The Evidence}

Several issues arise when one empirically tests equations 1-4. Table 1 shows that the dollar has appreciated by significantly different amounts when measured by the exchange rate index weighted by bilateral import share instead of by the Federal Reserve index, which is weighted by multilateral trade share. The appropriate choice of exchange rate index depends on one's model of price interactions and on the question that is being asked. For explaining export prices and the influence on the domestic price level of overall trade through competition in every national market, the Federal Reserve's multilateral-weight index may be the best. On the other hand, if the price of imports is the main channel affecting domestic inflation, then the bilateral import-share index may be the most suitable indicator. These considerations suggest the use of the multilateral exchange rate index for the export price equation and the bilateral import-share exchange rate index for the import price equation. However, because previous studies have generally focused on the multilateral-weight index, it is used as an alternative in all equations to provide comparability with other results.

The choice of time period is important for empirical study of exchange rate effects. A major change of regime occurred in 1973:1 when the Bretton Woods system of adjustable pegs was replaced by floating exchange rates. This may have altered the responsiveness of domestic prices to exchange rates. Furthermore, price and wage controls affected price and wage behavior from 1971:1 to $1975: 1 .{ }^{6}$ For these reasons, the relations considered here are estimated over the period from 1975:2 to the present.

The fixed-weight consumption deflator is explained, instead of the consumer price index, ${ }^{7}$ because the latter treated housing inappropriately

6. Perry omitted the data from this period in his study on wage behavior, and Gordon used complicated dummies to control for the distortion. See George L. Perry, "Inflation in Theory and Practice," BPEA, 1:1980, pp. 207-41, and Robert J. Gordon, "Output Fluctuations and Gradual Price Adjustment," Journal of Economic Literature, vol. 19 (June 1981), pp. 493-530.

7. Estimations using the CPI gave similar results. In addition, all estimations were made with fixed-weight and implicit deflators. The answers were the same for the two deflators except for table 6 , and there both sets of estimation are reported. 
before 1983. In all the estimations I use the first-differenced form of the equations, because correct statistical testing under instrumental variable estimation requires that the population variance of the right-hand-side variables be finite.

Because each equation uses contemporaneous endogenous variables, simultaneity is a significant issue and has to be addressed. ${ }^{8}$ To do this the key results in each table were reestimated using instrumental-variable estimation with unconstrained lags. This method provides a check on the robustness of the results obtained from ordinary least squares with Almon lags.

For equations 1 and 2, theory tells us what the coefficients should be under two extreme cases. At one extreme, where the United States is a price taker in the world market, the foreign unit labor cost coefficient would be 1.0, the exchange rate coefficient would be -1.0 , and the U.S. unit labor cost coefficient would be insignificantly different from zero. At the other extreme, where the United States is the price setter, there would be a coefficient of 1.0 for U.S. unit labor cost and zero-value coefficients for the exchange rate and foreign unit labor cost.

The estimation of equation 1 is shown in table 2 . The instrumental variable estimations with the lags unconstrained yield the same results as the ordinary least squares estimations with Almon lags. Because the coefficient estimates from the former are free of simultaneity bias, the preferred equations for explaining the import deflator are 2-6 and 2-8.

There are two noteworthy results in table 2 . The first is that domestic labor costs are more important than foreign labor costs in determining the prices of foreign imports. This suggests that foreign manufacturers price the product they export to the U.S. market according to U.S. cost conditions rather than according to the costs in their own countries. The second finding is that the pass-through of an exchange rate movement is less than complete. All the exchange rate coefficients are less than 1.0 in absolute value, though their sign is as expected. Although the coefficients associated with the two exchange rate indexes are very different, historically both indexes attribute the same amount of change in the import deflator to exchange rate movements. The 43 percent

8. The simultaneity problem occurs when any of the right-hand-side variables is correlated with the contemporaneous error term. This can cause ordinary least squares to yield biased results. 


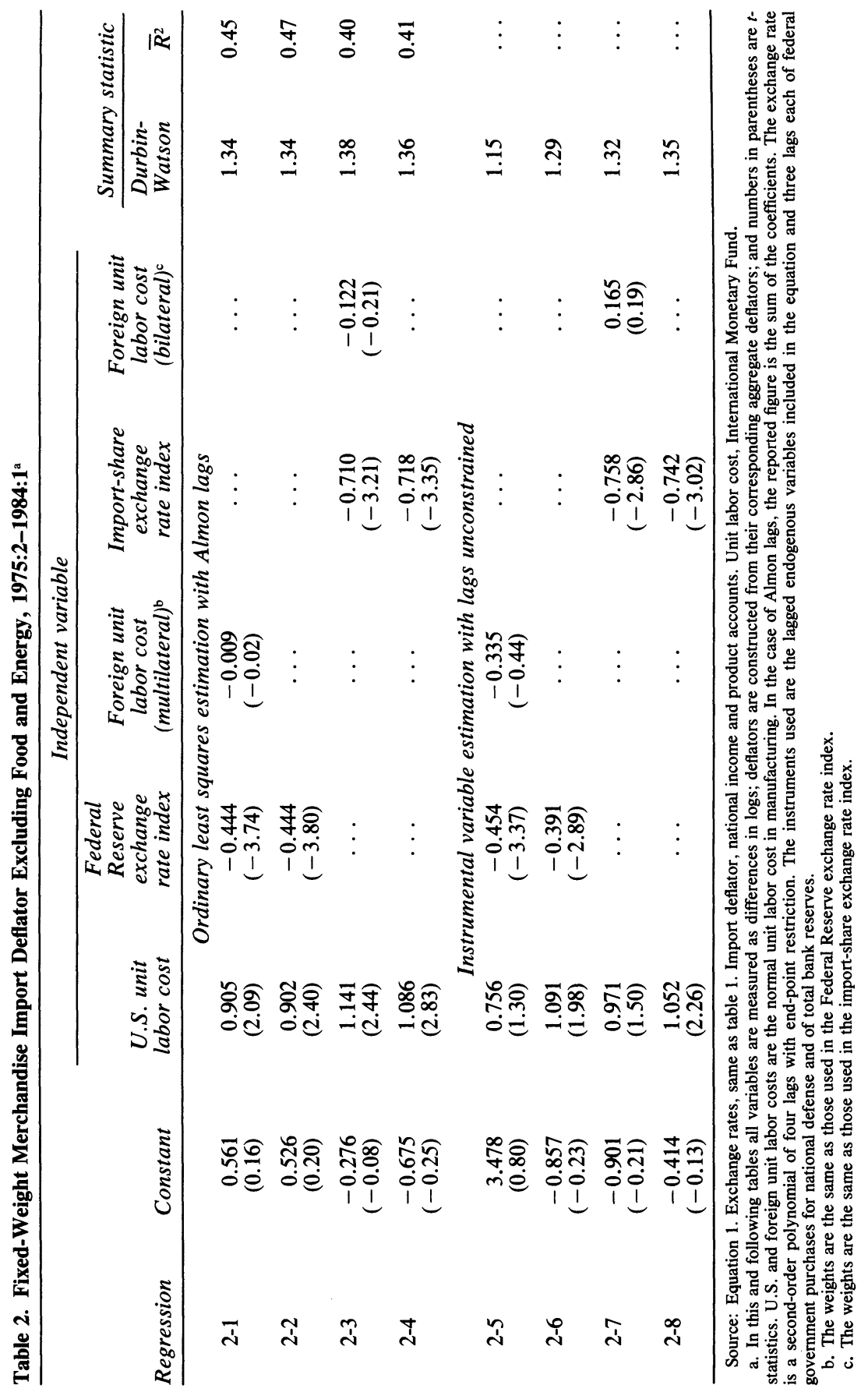


Table 3. Fixed-Weight Merchandise Export Deflator Excluding Agricultural Products, 1975:2-1984:1 ${ }^{\text {a }}$

\begin{tabular}{|c|c|c|c|c|c|c|}
\hline \multirow[b]{3}{*}{$\begin{array}{c}\text { Regres- } \\
\text { sion }\end{array}$} & \multirow[b]{3}{*}{ Constant } & \multicolumn{3}{|c|}{ Independent variable } & \multirow{2}{*}{\multicolumn{2}{|c|}{$\begin{array}{l}\text { Summary } \\
\text { statistic }\end{array}$}} \\
\hline & & \multirow[b]{2}{*}{$\begin{array}{l}\text { U.S. unit } \\
\text { labor cost }\end{array}$} & \multirow{2}{*}{$\begin{array}{l}\text { Federal } \\
\text { Reserve } \\
\text { exchange } \\
\text { rate index }\end{array}$} & \multirow{2}{*}{$\begin{array}{c}\text { Foreign unit } \\
\text { labor cost } \\
\text { (multilateral) }\end{array}$} & & \\
\hline & & & & & $\begin{array}{l}\text { Durbin- } \\
\text { Watson }\end{array}$ & $\bar{R}^{2}$ \\
\hline \multicolumn{7}{|c|}{ Ordinary least squares estimation with Almon lags } \\
\hline $3-1$ & $\begin{array}{r}0.353 \\
(0.13)\end{array}$ & $\begin{array}{r}1.003 \\
(2.87)\end{array}$ & $\begin{array}{l}-0.128 \\
(-1.34)\end{array}$ & $\begin{array}{c}-0.051 \\
(-0.01)\end{array}$ & 1.78 & 0.30 \\
\hline $3-2$ & $\begin{array}{r}0.334 \\
(0.15)\end{array}$ & $\begin{array}{r}1.001 \\
(3.30)\end{array}$ & $\begin{array}{l}-0.128 \\
(-1.37)\end{array}$ & . . & 1.78 & 0.33 \\
\hline \multicolumn{7}{|c|}{ Instrumental variable estimation with lags unconstrained } \\
\hline $3-3$ & $\begin{array}{l}-0.436 \\
(-0.13)\end{array}$ & $\begin{array}{r}1.091 \\
(2.37)\end{array}$ & $\begin{array}{r}-0.142 \\
(-1.33)\end{array}$ & $\begin{array}{r}0.039 \\
(0.07)\end{array}$ & 1.93 & $\ldots$ \\
\hline $3-4$ & $\begin{array}{c}-0.769 \\
(-0.25)\end{array}$ & $\begin{array}{l}1.170 \\
(2.67)\end{array}$ & $\begin{array}{r}-0.123 \\
(-1.14)\end{array}$ & . . & 1.97 & . \\
\hline
\end{tabular}

Source: Equation 2. Data sources, same as table 2.

a. See notes to table 2 .

appreciation of the Federal Reserve exchange rate index from 1980 to 1983 accounts for a 17 percent decline in the import deflator, while the 21 percent appreciation of the import-share exchange rate index accounts for a 16 percent fall in import prices. ${ }^{9}$

The equations in table 3 for the pricing of U.S. nonagricultural exports show that the exchange rate has only a small estimated effect. U.S. cost conditions are the most important factor determining export prices. The finding that competitive pressures in foreign markets do not influence U.S. export prices suggests that U.S. firms in general regard foreign demand as residual demand. This overall insensitivity of U.S. export prices to foreign factors is in line with the work of Artus and Lawrence. ${ }^{10}$ The results from the import price and export price equations provide support for the usual asymmetrical practice of specifying U.S. price

9. Calculated from regressions 2-6 and 2-8, respectively.

10. Jacques R. Artus, "The Behavior of Export Prices for Manufactures,"' in Peter B. Clark, Dennis E. Logue, and Richard James Sweeney, eds., The Effects of Exchange Rate Adjustments (U.S. Department of the Treasury, 1974), pp. 319-40, and Robert Z. Lawrence, "Toward a Better Understanding of Trade Balance Trends: The Cost-Price Puzzle," BPEA, 1:1979, pp. 191-210. 


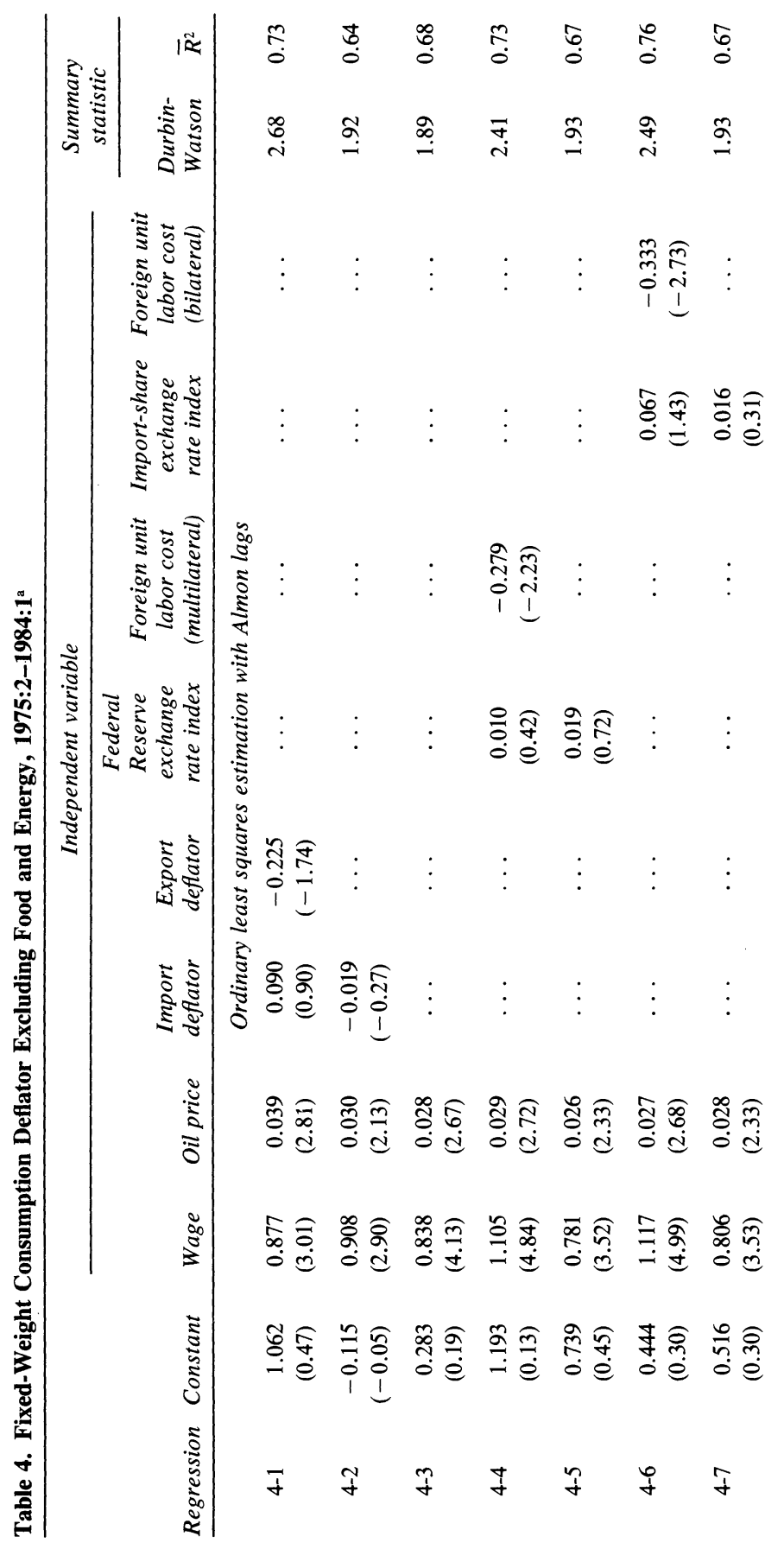




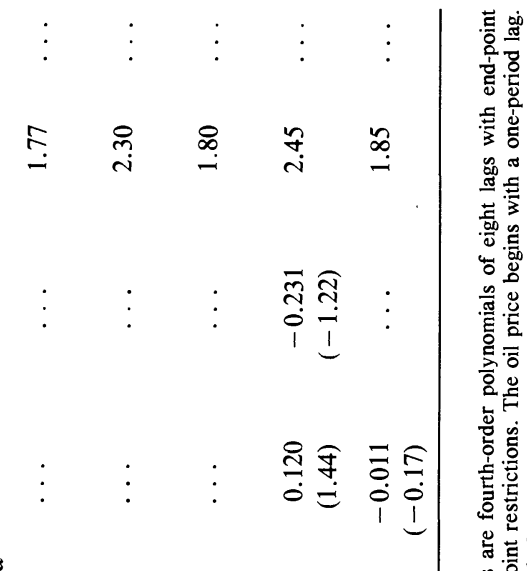

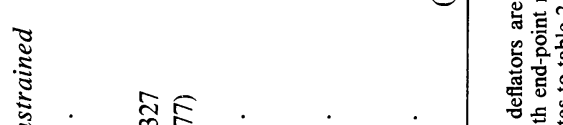

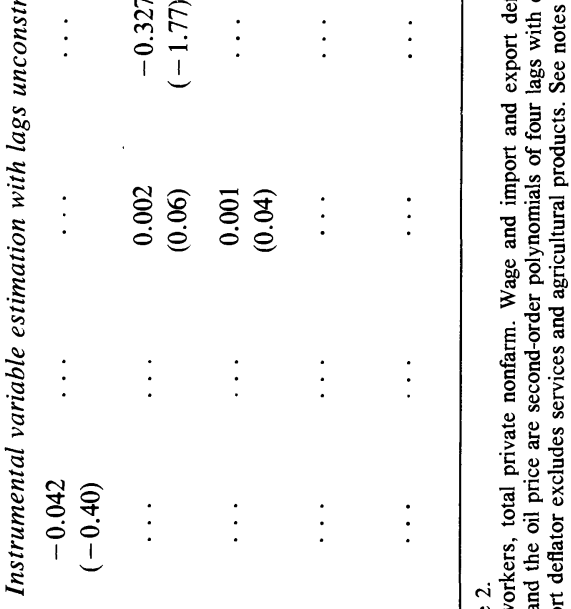

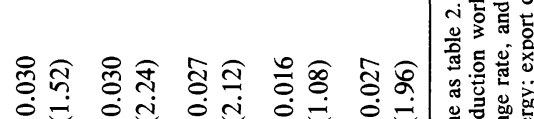

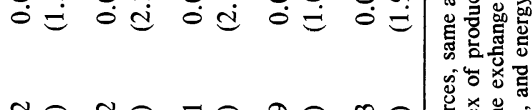

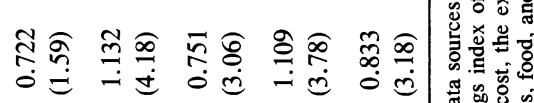

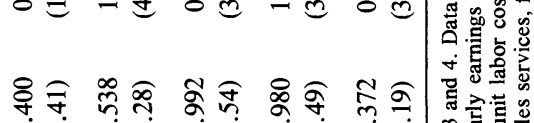

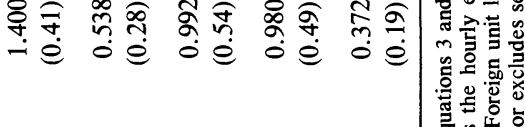

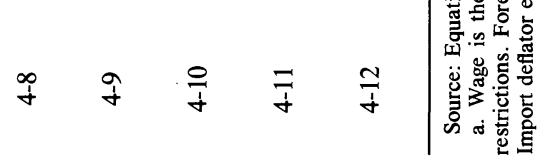


equations to include the import deflator but not the export deflator. ${ }^{11}$

The determinants of the nonfood, nonfuel consumption deflator are examined in table 4 . The insignificance of competitive pressure from foreign markets as a factor in U.S. inflation is borne out in regression 4-1, where the export deflator even has the wrong sign; the surprising finding, from regression 4-2, is that the import deflator does not affect the price level either. These point estimates imply that there is no direct price effect from exchange rates. Regressions 4-4 to 4-7 represent my attempt to look further for a direct exchange rate effect by substituting the exchange rate and foreign unit labor cost for the import deflator. The exchange rate is invariably insignificant and has the wrong sign. The foreign unit labor cost variable fares even worse, being significant with the wrong sign. Regression 4-3, which eliminates all foreign trade variables except the price of imported oil, is the only specification in which all the coefficients have the expected signs.

Note, however, that the $t$-statistics on import prices and exchange rates in table 4 are generally very low. Table 5 summarizes the key coefficient estimates and the one-standard-error and two-standard-error confidence intervals of those estimates. The table also gives the priors for the coefficients under two hypotheses: the first is complete passthrough of the exchange rate to import prices together with full passthrough of import prices to U.S. consumer prices; the second accepts the exchange rate elasticity estimated in table 2 and assumes full passthrough of import prices to U.S. consumer prices. It should be noted that hypotheses that call for import prices to affect prices of domestically produced substitutes would attribute larger price effects to import prices than what we here call full pass-through. ${ }^{12}$

Table 5 shows that in no case is the prior of full exchange rate pass-

11. Franco Modigliani and Lucas Papademos, "Targets for Monetary Policy in the Coming Year,' BPEA, 1:1975, pp. 141-63; Rudiger Dornbusch and Paul Krugman, "Flexible Exchange Rates in the Short Run," BPEA, 3:1976, pp. 537-75; Sung Y. Kwack, "Price Linkages in an Interdependent World Economy: Price Responses to Exchange Rate and Activity Changes," in Joel Popkin, ed., Analysis of Inflation: 1965-74 (Ballinger, 1977), pp. 447-77; Erich Spitäller, "A Model of Inflation and Its Performance in the Seven Main Industrial Countries: 1958-76," IMF Staff Papers, vol. 25 (June 1978), pp. 254-77; and Rudiger Dornbusch and Stanley Fischer, "The Open Economy, Implications for Monetary and Fiscal Policy," paper prepared for the 1984 conference on business cycles, National Bureau of Economic Research.

12. Nonfood, nonfuel imports during this period are 5 percent of GNP, and if we assume a complete pass-through of import prices through the production process, then it will also be 5 percent of total consumption. Because nonfood, nonfuel consumption is 71 
Table 5. Error Band of Coefficient Estimates in Table 4

\begin{tabular}{|c|c|c|c|c|c|}
\hline Regression & $\begin{array}{c}\text { Point } \\
\text { estimate }\end{array}$ & $\begin{array}{l}\text { One-standard- } \\
\text { error band }\end{array}$ & $\begin{array}{l}\text { Two-standard- } \\
\text { error band }\end{array}$ & Prior $I^{\text {a }}$ & Prior $I^{\mathrm{b}}$ \\
\hline \multicolumn{6}{|c|}{ Import deflator } \\
\hline $4-2$ & -0.02 & -0.09 to +0.05 & -0.16 to +0.12 & +0.07 & . . \\
\hline $4-8$ & -0.04 & -0.14 to +0.06 & -0.25 to +0.17 & +0.07 & $\cdots$ \\
\hline \multicolumn{6}{|c|}{ Federal Reserve exchange rate index } \\
\hline $4-5$ & 0.02 & -0.01 to +0.04 & -0.03 to +0.07 & -0.07 & $-0.03^{c}$ \\
\hline $4-10$ & 0.00 & -0.03 to +0.03 & -0.06 to +0.06 & -0.07 & $-0.03^{c}$ \\
\hline \multicolumn{6}{|c|}{ Import-share exchange rate index } \\
\hline 4-7 & 0.02 & -0.04 to +0.07 & -0.09 to +0.12 & -0.07 & $-0.05^{\mathrm{d}}$ \\
\hline 4-12 & -0.01 & -0.07 to +0.05 & -0.14 to +0.12 & -0.07 & $-0.05^{\mathrm{d}}$ \\
\hline
\end{tabular}

a. Complete pass-through of exchange rate and import prices.

b. Estimated pass-through of exchange rate and complete pass-through of import prices.

c. Product of 0.07 and 0.4 , where 0.4 is the exchange rate coefficient in regression 2-6.

d. Product of 0.07 and 0.7 , where 0.7 is the exchange rate coefficient in regression $2-8$.

through with full import price pass-through (prior I) less than one standard error away from the estimated coefficient. Under this hypothesis, two of the six coefficients are more than two standard errors away from the prior. All coefficients fall within two standard errors of the prior when the assumption of full exchange rate pass-through is relaxed, but note that the relaxation of this assumption puts only one of the four coefficients within the one-standard-error band. While the evidence cannot reject prior II at the usual significance level, the evidence does not support this hypothesis with more than 50 percent certainty. With some confidence, we can conclude that the exchange rate affects consumer prices by no more than the weight of imports in total consumption. This implies that, across all goods in the economy, competitive effects on the prices of non-oil import-competing goods appear to be small or even zero.

It is possible that automobiles, protected by import quotas on Japanese cars, dominate the effect of import prices found in these regressions. To explore the importance of autos and to sharpen the coefficient estimate on other import prices, I removed services and automobiles (old and new) from the nonfood, nonfuel consumption deflator and automobile imports from the nonfood, nonfuel import deflator used previously; the results are in table 6. As suspected, autos are important in the results of table 4, with the table 6 results showing insignificant but correctly signed coefficients using the fixed-weight consumption deflator. For some

percent of total consumption, the expected import price coefficient in regression 4-2 is 0.07 . 


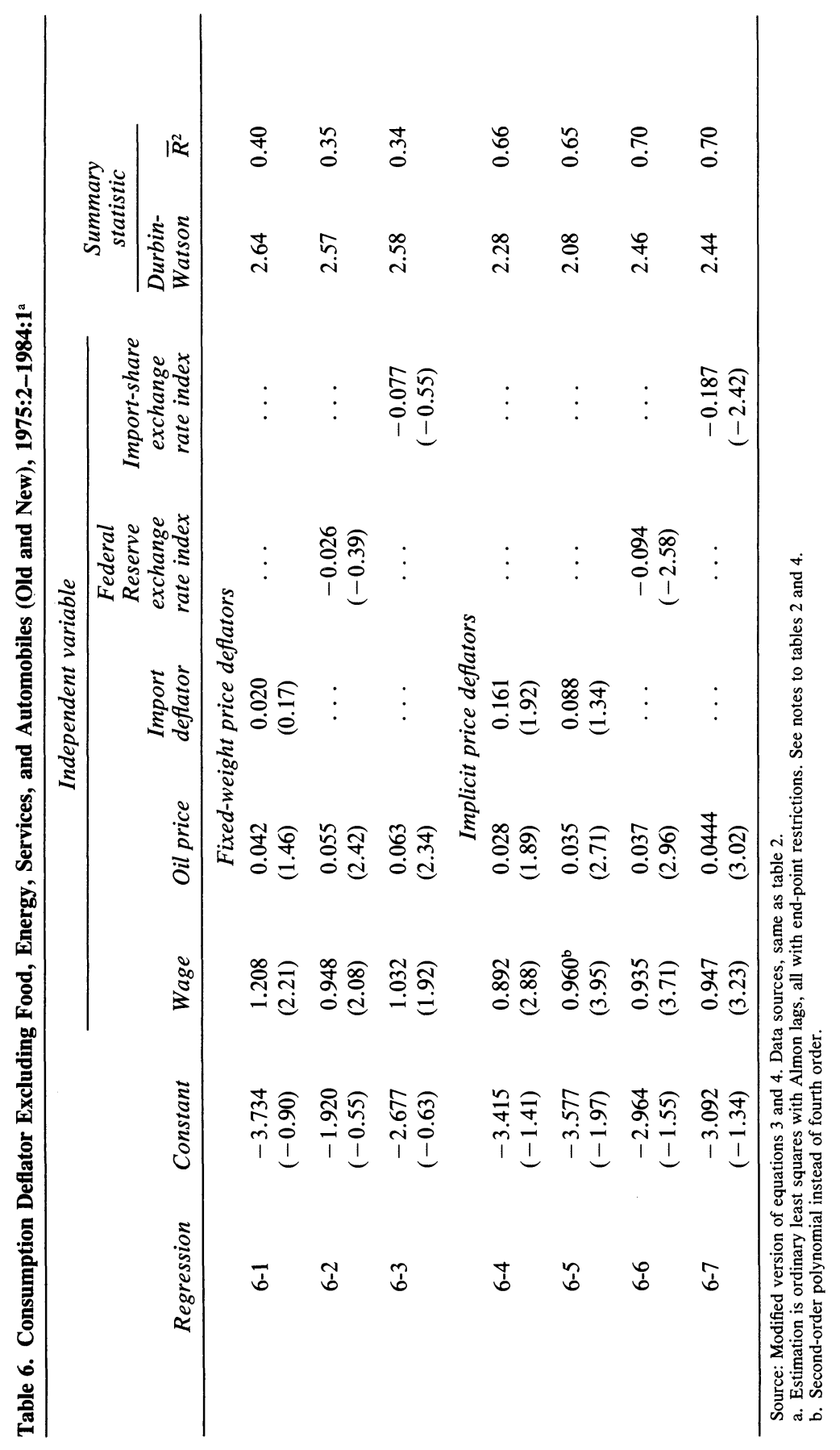


reason, the results are substantially stronger using the implicit deflator, which in principle is not an appropriate price index. ${ }^{13}$ Furthermore, the significance of the import deflator varies with the Almon constraint on wage: wage is a fourth-order polynomial in regression 6-4 and a secondorder polynomial in regression 6-5. The strongest evidence we can marshall is that a 10 percent rise in the price of nonfood, nonfuel, nonautomobile imports will raise the total consumption deflator by 0.37 percentage point. A 10 percent fall in the Federal Reserve exchange rate index, if it does not affect oil, food, or auto prices, will increase the total consumption deflator by 0.22 percentage point. ${ }^{14}$

Table 7 illustrates the role of energy prices in reconciling the present results with studies that found large price effects from the exchange rate. In the top half of the table, agricultural and petroleum products are not excluded from the price indexes. The total merchandise import deflator is highly significant and suggests that a 10 percent rise in the import deflator will raise the consumption deflator by 1.6 percentage points. A 10 percent depreciation of the Federal Reserve exchange rate index will have a direct price impact of 1.0 percentage point.

Oil is excluded from the consumption and import deflator in the second half of table 7, and in contrast with table 4, food is left in; in this case the import deflator and the exchange rate become insignificant. These results suggest that a major reason for the significance of the import deflator in a number of studies is their inclusion of the price of oil. There was a correlation between U.S. exchange rate depreciation in the 1970s and OPEC actions raising world oil prices. But data from that period do not provide a useful answer to policy concerns about exchange rate depreciation unless one assumes that a similar correlation will exist in the future.

Note that the presence of food in the consumption deflator makes the export deflator (which includes agricultural products) significant and that the exchange rates have the right sign. As noted previously, food is a homogeneous product traded under competitive conditions; hence prices for food should be more responsive to exchange rate movements

13. As noted previously, table 6 is the only case whose implicit deflators give results different from fixed-weight deflators.

14. These figures are calculated from regressions 6-4 and 6-6 using the fact that the basket of goods in table 6 is 23 percent of total consumption over this period. 


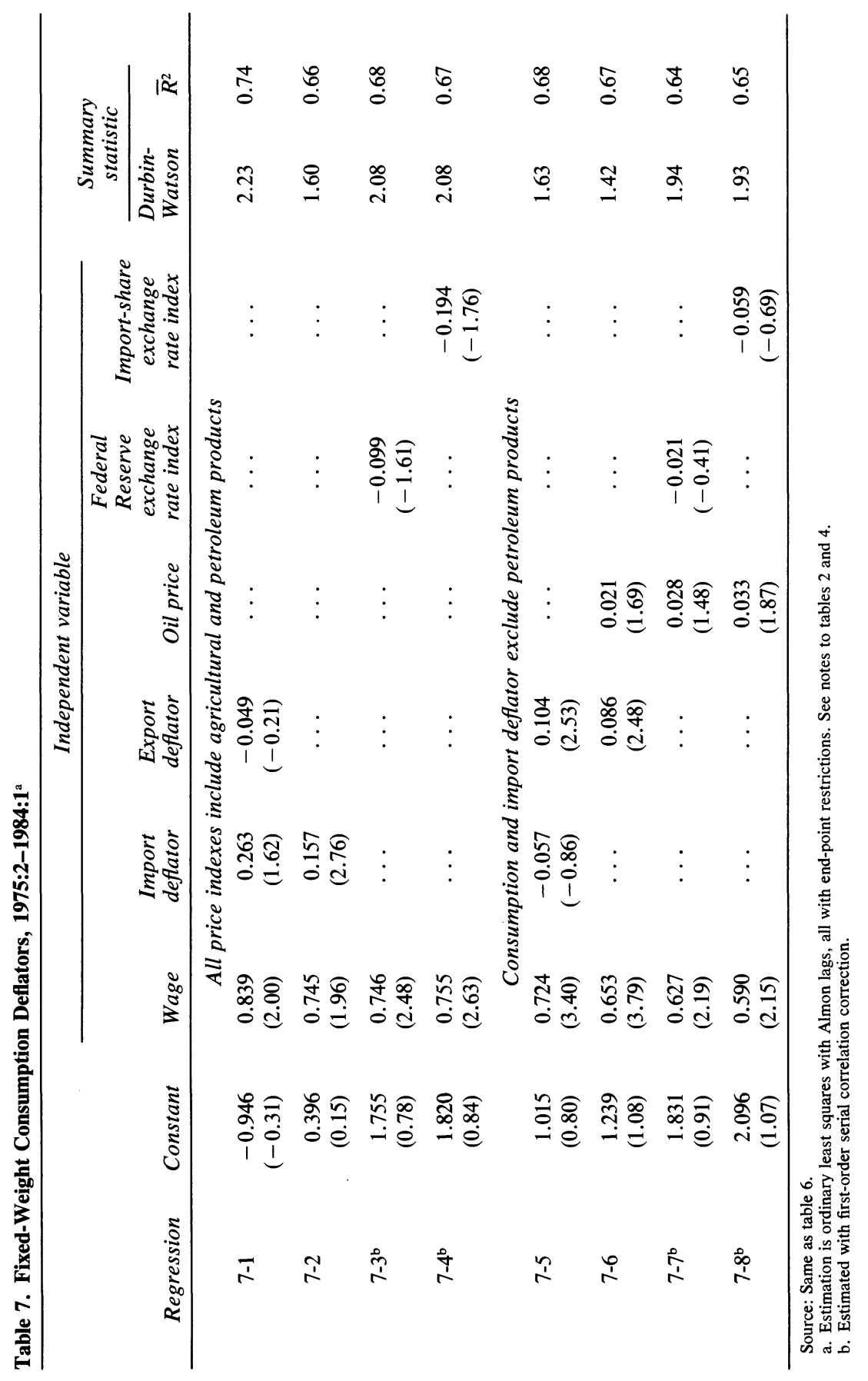


than prices for goods that are imperfect substitutes. I interpret the small $t$-statistics of the exchange rates as confirming my argument that food prices ought to be modeled separately and that it is wrong to include them within a cost-markup equation.

\section{Conclusion}

The insignificance of the external sector after accounting for the traditional causes of inflation-wage and oil price-suggests that pricing behavior in traded goods largely reflects U.S. prices rather than being an important cause of U.S. inflation. The fact that the exchange rate adjustment shows up in the import deflator but may not be present at the retail level indicates that the dealers of foreign products are allowing the quasi rents of their distributorships to fluctuate with exchange rate movements. Their great emphasis on maintenance of market share may be due to some of the following reasons.

Overall the evidence from import pricing supports the view that foreign manufacturers price their products according to U.S. demand and cost conditions with some adjustment (approximately 40 percent by the Federal Reserve index and 70 percent by the import-share index) for exchange rate changes. This outcome is consistent with a wide range of hypotheses about pricing behavior. The United States is such a large market that it effectively sets the world price. Foreigners can discriminate by price, selling their products dear in countries with high labor costs and cheap in countries with low labor costs. Foreigners are afraid of provoking U.S. protectionism when U.S. competitors are driven out of the domestic market. Foreigners may also be wary of the potentially harmful consequences of starting a price war with their U.S. competitors. The last two considerations may be the reasons that distributors of foreign goods allow their profit margins to move with the exchange rate in order to preserve relative market shares.

However, it is likely that none of the above is the sole explanation. We do not expect all markets in the U.S. nonfood, nonfuel sector to be large vis-à-vis the rest of the world, to have the same market imperfection, or to cause foreigners and their distributors to have the same kind of strategic considerations. The observed aggregate phenomenon may be the result of these disparate factors operating in different markets. 
The best price equation in table 4 is regression 4-3, and it attributes the current slowdown in the inflation rate to lower wage demands and lower oil prices. ${ }^{15}$ It is likely that this change in wage behavior is more the result of the deep recession in 1981-83 than of firms and workers holding wages down in the face of intense import competition brought about by the strong dollar. It is hard to argue on the one hand that import prices tend to be set in line with U.S. domestic goods prices, whose primary determinant is wages as the results here suggest, and on the other hand that wages are highly sensitive to import prices ${ }^{16}$ If domestic producers do not change their prices in response to foreign prices, then there is no competitive pressure on workers to decrease their wage demands. The conclusion is that the primary determinants of inflation in the period of our study are wage demands and oil prices, and they are largely determined, respectively, by aggregate demand policies and OPEC actions.

This is not to say that the strong dollar had no effects on the moderation of wage demands. The appreciation of the dollar did hurt U.S. export and import-competing industries and hence helped to deepen their recession. The point is that the main price effects of the strong dollar have been indirect ones in the form of weaker demand. It should be emphasized that this paper has not provided proof that exchange rate movements have no direct effects on the nonfood, nonfuel consumption deflator. The evidence does not reject the view that there are direct effects and that they could be as large as the weight which nonfood, nonfuel imports have in the consumption deflator, though the point estimates are much smaller than this. The evidence is definitely not consistent with the view that, overall, non-oil import competition has much greater effects through the prices of import-competing goods; however, this view may be applicable to other countries.

15. I think that the oil price drop in $1982-83$ was largely due to weak global demand rather than to the strong dollar.

16. I am not claiming that there are no cases in which wage demands are dependent on the exchange rate but only disputing the significance of this dependence in the aggregate. I think that the only labor union that seriously took the exchange rate into account in wage negotiations is the United Automobile Workers. 


\section{Comments and Discussion}

Peter Hooper: The effect of exchange rate changes on domestic prices is an issue that has attracted considerable empirical work over the past decade of floating exchange rates. Much of the work during the 1970s formed a basis for what I will call the conventional view that there exists a significant structural or partial-equilibrium relationship running from exchange rates to domestic prices through changes in import prices. Wing Woo's report raises a serious question about the conventional view. His empirical results suggest that these effects of exchange rate changes on domestic prices (through import prices) could very well be negligible, and he concludes that the appreciation of the dollar probably has not played an important role in reducing U.S. inflation over the past four years.

The resolution of this question is of interest to policy analysts, not only because the exchange rate represents a potentially important channel through which changes in domestic policy affect domestic prices, but currently in particular, because the dollar appears to many observers (including some economists) to have taken on a life of its own or, in Robert Shiller's new terminology, to have become quite the "fad" among international investors. A shift in international preference away from dollar assets resulting in a sharp decline in the dollar could have significantly different implications for the near-term inflation outlook, depending upon how Woo's results are interpreted. To give you an idea of the quantitative magnitude involved, a survey of empirical estimates of this structural relationship, when plugged into macroeconomic models maintained by the Federal Reserve Board staff, suggests that the dollar's real appreciation from mid-1980 to date, by itself, will have reduced the average annual inflation rate by 1 to 2 percentage points for a period of 
about six years. ${ }^{1}$ Where one lies within this 1 to 2 percentage point range depends upon one's assumptions about the underlying stance of monetary policy and a number of other factors.

Let me summarize the essential features and the limitations of Woo's analytical framework. He adopts the fairly standard structural approach of estimating markup price equations for both import prices and domestic consumer prices. He also includes an export price equation in the analysis, although this had little impact on the results. The import price equation tests for the impact of exchange rates on import prices, correcting for other factors that directly influence import prices. And the domestic price equation tests for the impact of import prices on domestic prices, correcting for other factors that directly affect domestic prices. The coefficient on import prices in the latter equation captures effects that take place through input costs, domestic competitive effects, and the prices of imported final goods that appear directly in the domestic price index.

The major limitation of this analytical framework is that it tells only part (albeit an important part) of the story concerning the relationship between exchange rates and domestic prices. The other structural determinants of domestic and import prices (such as domestic and foreign labor costs, aggregate demand pressure, and commodity prices), which are essentially treated exogenously in the analysis, can also be significantly influenced by the exchange rate. Calculating the full price effect of an exchange rate change requires plugging these structural price equations into a more complete macroeconomic model that determines all of the endogenous determinants of prices. Another limitation of the analysis is that the exchange rate itself is an endogenous variable. The general-equilibrium relationship between that variable and domestic prices can vary considerably, depending upon the exogenous shocks ultimately responsible for the exchange rate change and how the shock affects domestic prices through channels other than the exchange rate. In fairness to the author, he does recognize most of these limitations at one point or another in his paper.

Despite the limitations, Woo's analysis is important because it addresses two key structural parameters within the more general relation-

1. Peter Hooper and Barbara Lowrey, "Impact of the Dollar Depreciation on the U.S. Price Level: An Analytical Survey of Empirical Estimates," Staff Study 103 (Board of Governors of the Federal Reserve System, April 1979). 
ship between exchange rates and domestic prices. The stability of these parameters has significant implications for estimates of the price effects of various exogenous shocks that influence the exchange rate. As in previous studies, Woo finds that exchange rates have a significant (and relatively stable) direct effect on import prices, but he fails to find a stable structural coefficient on import prices in the domestic price equation.

Woo's approach differs from the earlier work in that he excludes food and oil prices from the analysis. He argues that goods whose prices are either determined in competitive markets or that are set by cartels do not belong in a framework that models price determination as a markup over costs of production. This refinement leads to expressing domestic prices excluding food and oil as a function of separate price terms for nonfood, non-oil imports and for oil, among other factors. By comparison, much of the earlier work related total domestic prices to total import prices. Total import prices generally yield a significant and stable coefficient in a domestic price equation, as indicated in table 7 of the paper. Woo's finding that this effect stems from the effect of oil prices on a total consumption deflator is consistent with the findings of a recent study at the Federal Reserve. ${ }^{2}$

Woo finds that a significant relationship between nonfood, non-oil import prices and domestic consumer prices emerges when the domestic price equation is refined further by removing services and automobiles (in addition to food and oil) from the left-hand-side variable. However, the coefficient estimate obtained for import prices indicates a much smaller impact on total domestic prices than conventional estimates suggest. This specification ignores the potentially important role of imports as inputs into the excluded sectors. Less than one-fifth of U.S. imports can be described as final consumer goods-about half are raw materials and intermediate goods and another one-fourth are capital goods.

The paper offers an explanation for the lack of a consistent empirical relationship between non-oil import prices and domestic prices. Woo suggests that domestic distributors of imported goods may have been willing to absorb changes in import prices by adjusting their profit

2. James E. Glassman, "The Influence of Exchange Rate Movements on Domestic Inflation: A Reconciliation of Traditional Empirical Estimates"' (Board of Governors of the Federal Reserve System, November 1983). 
margins in order to stabilize their domestic prices and maintain their market shares. However, such pricing behavior is not consistent with the markup model that is being employed, and a plausible microfoundation for this explanation is not immediately apparent. Do we have domestic producers that are price setters and importers that both act as price takers in the domestic market and do not compete with one another? In any event, it is worth noting that the relative price of non-oil imports fell by more than 20 percent between early 1981 and mid-1983, which would imply a significant movement in profit margins, particularly for distributorships. Some corroborative evidence on this point is neededif possible, in the form of direct measures of profit margins among import distributors.

As an alternative explanation, the instability of the non-oil price coefficient across different specifications could reflect simply a problem with collinearity. The simple correlation between changes in U.S. cil and non-oil import prices alone (over Woo's estimation sample period) is about 0.5 . One would hesitate to draw strong conclusions about the results in the presence of this collinearity.

Finally, I would like to explore the connection between the prices of food and oil imports and the exchange rate, a topic not treated in Woo's analysis. One would expect the domestic prices of goods that are traded competitively on world markets to reflect changes in exchange rates at least to some degree. Abstracting from differences in price elasticities of consumption and production across countries, simple comparative statics suggest that if the United States and other countries whose currencies are tied to the dollar account for, say, half of the total world consumption and production of a competitively traded good, an appreciation of the dollar against all other currencies will result in a decline in the dollar price of the good by half as much as the change in the exchange rate.

This argument clearly pertains to food commodities. It may also pertain to oil, to some extent. It is generally recognized that OPEC contract prices have been significantly influenced by competitive spot market prices. The relative price of OPEC's oil exports has declined by roughly 20 percent since early 1981 , shortly after the dollar started to appreciate. As Woo points out, much of the decline probably reflects the recession and lagged response to the earlier oil price increases. However, the substantially higher oil prices facing countries whose 
currencies were falling against the dollar must have had some effect on their oil consumption and production, and therefore on the spot market price of oil, and ultimately on U.S. consumer prices.

\section{General Discussion}

Several explanations were offered for the seemingly weak relation that Woo had found between import prices and the consumption deflator. Lawrence Klein felt that the single equation approach is incapable of giving a precise estimate. A more disaggregated approach that separates imports into consumer goods, capital goods and intermediate inputs and traces each component through the economy would be theoretically more satisfying. He argued that the purchasing power parity relationship ought to hold in the long run, and the fact that Woo's equations do not yield this result indicates they are misspecified. Klein added that the official OPEC pricing formula, presently in abeyance, does have an exchange rate in it so that oil prices may need to be treated as sensitive to exchange rates.

Richard Cooper was skeptical about the absence of exchange rate effects in the pricing of domestically produced goods. So many complaints from the steel, textile, and automobile industries about competitive pressures from imports testify to the contrary. Furthermore, many countries have conducted their monetary policies with the aim of influencing the value of their exchange rates because their experiences have suggested that the exchange rate has a powerful effect on their price levels. The present U.S. quotas on several major import items are a response to foreign competition, indicating such effects are potentially important in the United States. However, by keeping prices above the free trade level, quotas effectively eliminate the impact of exchange rate movements on domestic prices, helping to produce Woo's results. Cooper also noted that the degree of exchange rate pass-through may depend importantly on whether the exchange rate movement is regarded as temporary or permanent.

Woo noted that the United States is the world's largest economy and that its ratio of trade to GNP is the smallest in the OECD. This would lead one to expect that the impact of exchange rate movements is much smaller for the United States than for other countries. He agreed with 
Cooper that the protection provided by quotas was another reason for such results.

Stanley Fischer argued that the paper should have considered the direct effects of the exchange rate on wages, and reported that in work with Rudiger Dornbusch, they found that the exchange rate entered significantly into a Phillips curve specification. Robert Gordon agreed that the exchange rate could logically enter into the wage equation, but reported that in his own work, when he had replaced the wage variable with its determinants, the exchange rate was significant only if data after 1980 were omitted. In addition, his price equation passes the Chow test of stability only if the exchange rate is excluded. This may indicate that firms' decisions on profit margins are asymmetrical to exchange rate movements, with behavior different when the dollar was depreciating from when it was appreciating. Woo responded that some pressure could come directly from the exchange rate to wages, though it was hard to investigate this possibility except through a Phillips curve framework. And evidence of shifts in the short-run Phillips curve already had an excess of possible explanations. But it was hard to believe this effect was strong when it did not show up in pressure on price margins in his equations. 